\title{
Macroalgal Population and Sustainability
}

\author{
Philippe Morand ${ }^{\dagger}$ and Michel Merceron \\ †NRS-Université de \\ Rennes 1 \\ Station biologique \\ F-35380 Paimpont, France \\ Philippe.Morand@univ- \\ rennes1.fr \\ *IFREMER \\ Centre de Brest \\ F-29280 Plouzané, France
}

\begin{abstract}
MORAND, P. and MERCERON, M., 2005. Macroalgal population and sustainability. Journal of Coastal Research, 21(5), 1009-1020. West Palm Beach (Florida), ISSN 0749-0208.
\end{abstract}

Algal blooms, often associated with eutrophication, are common in temperate regions in coastal lagoons and estuarine areas as well as in open seas. However, because of recent changes in water flows and sediment and nutrient loads in most rivers, eutrophication phenomena are now occurring in areas previously non affected. One of its most widespread and easily recognized effects in a coastal marine ecosystem is the excessive growths and drifts of macroalgae, to such a degree that the biomass becomes a significant problem.

The nutrients, notably from anthropogenic origin, constitute a significant factor in the appearance of the blooms in coastal waters. Besides a background originating from natural areas and precipitations, nutrients come from agriculture, sewage, industry, and aquaculture, in very various proportions following the local conditions.

At first, the development of opportunist and tolerant seaweeds acts as a purifying system. Then, when the seaweed is stranded or the environmental conditions become unfavourable, the plants die and decompose. The degradation of the chemical equilibrium induces the break-down of the biological balance in the ecosystem. At this stage, a large biomass can become troublesome, resulting in an increase in the herbivore population, competition or toxicity towards flora and fauna, alteration of the sediment, recycling of nutrients and pollutants in the ecosystem, nuisance for local residents and reduction of tourism (beaches degradation, chironomids, odors). Sooner or later, the water deteriorates, which may have a toxic effect on fauna including the commercial fish stocks.

Eutrophication problems have thus become a matter of major concern. Its management is neither a simple nor a cheap task. But, environmental and sustainability concerns may, in a not too distant future, override the lack of financial benefit. At any rate, underlayed action is required because in estuarine and potamologic milieus, potential land disposal arrangements are becoming rarer and costlier.

Control of eutrophication can only be reached effectively by drastic reduction of the total nutrient load of an overloaded water system. In order to be successful, only an integrated approach, based on a water body's nutrient mass balance and taking into consideration specific geographical, climatological and ecological conditions, can be effective. Moreover, it may take many years before recovery of a eutrophicated ecosystem, because the sediments constitute a complementary source of nutrients for macroalgae. But, prevention will prevent the nutrients from being discharged in the lagoons or in the sea. It will concern the waste treatment, agricultural mode change and treatment of gaseous effluent from polluting human activities.

ADDITIONAL INDEX WORDS: Black Sea, nutrients, eutrophication, macroalgae, green tides.

\section{INTRODUCTION}

Obviously, transformations of ecosystems quicken. Until now, people could think that scientific progress would permit them to go beyond the limit that the planet imposes, such as resource limitations or pollution. Today, numerous examples show that, if drastic measures are not taken, and if inertia and interests are not put aside, changes which will occur inevitably will be irreversible or at best, not easily reversible. They will almost always be troublesome, principally because of their quick pace, which will not permit an adaptation without distress.

Such is the case for halieutic resources, in relation to which

DOI:10.2112/04-700A.1 received and accepted in revision 10 February 2004. the European Union proposes a significant reduction of fishing, a proposal badly accepted locally and yet globally profitable. Such is also the case for the global climate change, for which predictive models shorten the projected periods of perturbations (temperature increase, expected water-level rise, extreme atmospheric events) as they take into account various feedback phenomena initially neglected (release of methane from methane hydrates, increase of microbial activity, ...). Further, such is the case for the accumulation of wastes which multiply pollution and nuisances, managed as soon they are discovered, without global treatment of the problems at source point.

The lagoon or coastal ecosystems do not escape this fate. The phenomena of uncontrolled growths of marine flora increased during the twentieth century, both microalgae or macroalgae blooms and growths of toxic or invasive algae. If, 
locally different solutions could be found, for instance with hydraulic improvements, in order to diminish, even suppress, troublesome biomasses, the problem globally remains.

In this paper, we give an overview of the problem of the excessive growths of seaweed and of their consequences for the coastal areas. Having analysed their causes, we will try to see what can be, in the future, the evolution of the phenomenon, on the one hand through concrete examples, and on the other hand in the light of the evolution of the environmental context in which it develops. Finally, we will analyse the action possibilities to make our ecosystem "sustainable".

\section{EXCESSIVE GROWTH OF MACROALGAE}

\section{Definition and Characteristics}

A large concentration of macroalgal biomass which accumulates at some sites indicates an excessive growth of seaweeds. This biomass, either attached or free floating, decomposes in situ or accumulates high up on the beaches. Often confined to lagoons, bays and estuaries, these proliferations or accumulations are usually associated with industrial, urban, or agricultural areas. Excessive growth of macroalgae is a response, in a given biotope, to a supply, probably an oversupply, of nutrients of natural or anthropogenic origin; if anthropogenic, it results from an environmental disturbance (MorAND and BRIAND, 1996). In some locations, for example along the coast of Brittany in France, or in Puget Sound, Washington, U.S.A., the problem is characterized by the accumulation of the green alga Ulva in rows along the beaches (BRIAND, 1989; THOM and Albright, 1990). In such cases, the term "Green Tide" has been applied to the phenomenon (Figure 1) observed since times immemorial. It was reported to have occured as early as 1905 in Belfast Lough (LETTS and RICHARD, 1911), but seems to have increased in extent only over the last four decades, involving both the geographical expansion of these proliferations, and an increased biomass at the various sites. The years spanning 1960-1970 marked the real start of this phenomenon, limited until then to a very small number of localities.

Among the green proliferating algae, Ulva is the most commonly encountered, as in Brittany, France (BRIAND, 1989), or in the Venice Lagoon, Italy (SFRISo et al., 1993). Cladophora may be responsible for significant green tides, as in the southern Fyn archipelago, Denmark (THYBo-CHRISTESEN et al., 1993), or in Peel Inlet, Western Australia (LAVERY et al., 1991). Monostroma proliferates in Arcachon Bay (AuBY et al., 1994). Chaetomorpha and Enteromorpha also are often reported, the five genera being found alone, together, or dominant in turn (as in Peel Inlet). Gracilaria is the red alga the most involved in the excessive growths, as in Florida, U.S.A. (Virnstein and Carbonara, 1985). One brown alga, Pilayella, was mentioned, in Massachussets, U.S.A. (WILCE et al., 1982), in Brittany (Dion, personal communication), in the Baltic Sea (Lotze et al., 1999) and in the Southern Fyn archipelago (ThyBo-Christesen et al., 1993).

The density of algae in drift mats or run aground piles varies between 0.2 and $600 \mathrm{~kg} \mathrm{w} . \mathrm{w} . \mathrm{m}^{-2}$, and their depth falls within the $1 \mathrm{~cm}$ to $1.2 \mathrm{~m}$ range (DiAz Pifferez and Lopez, 1959; BRIAND, 1989). The biomass can be very significant, as

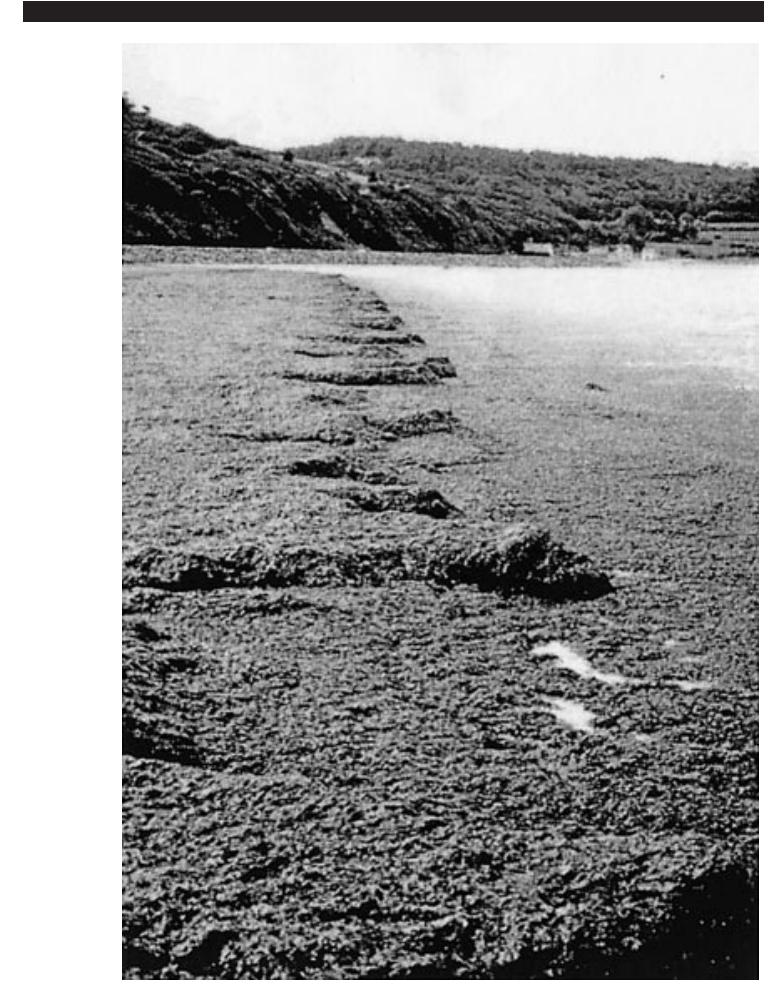

Figure 1. Green tide in Lannion Bay (Brittany, France).

in the Venice Lagoon $(600,000 \mathrm{t}$ fresh weight), in Brittany $(50,000-70,000 \mathrm{t})$, or in Peel Inlet $(100,000-600,000 \mathrm{t})$. The annual production may be estimated to be 1.5 to 4.5 times higher than the maximum biomass present at the site, in respect of an algal density high or low, as in the Venice Lagoon (SFriso et al., 1993). CASABIANCA-CHASsANY (1992) indicates a ratio of 2.6 in the Prévost Lagoon (France), based upon measurements of particulate nitrogen, and NIENHUIS (1992) reports a ratio of 3 for the Veerse Meer lagoon (Netherlands).

Table 1 provides some examples of recent macroalgae excessive growth occurrence in Europe.

\section{Consequences to the Ecosystem}

The effects of seaweed proliferation and accumulation on the biotope and the environment are both numerous and varied.

First, the seaweed biomass plays an important role in purifying the medium by absorbing excess nutrients and by accumulating some toxins (BRAULT, 1983). A primary function of excessive macroalgal development appears, therefore, to be the abatement of pollution in coastal ecosystems. Taking into consideration the entire cycle of growth and decay of the seaweed, the Venice Lagoon, for example, acts as an important denitrifying reactor (SFRISO and MARCOMINI, 1994).

Ulva concentrates several metals from water and is sometimes used to assess the level of this type of pollutants (MALEA and HARITONIDIS, 2000).

Associations between macrophytes and marine animals are 


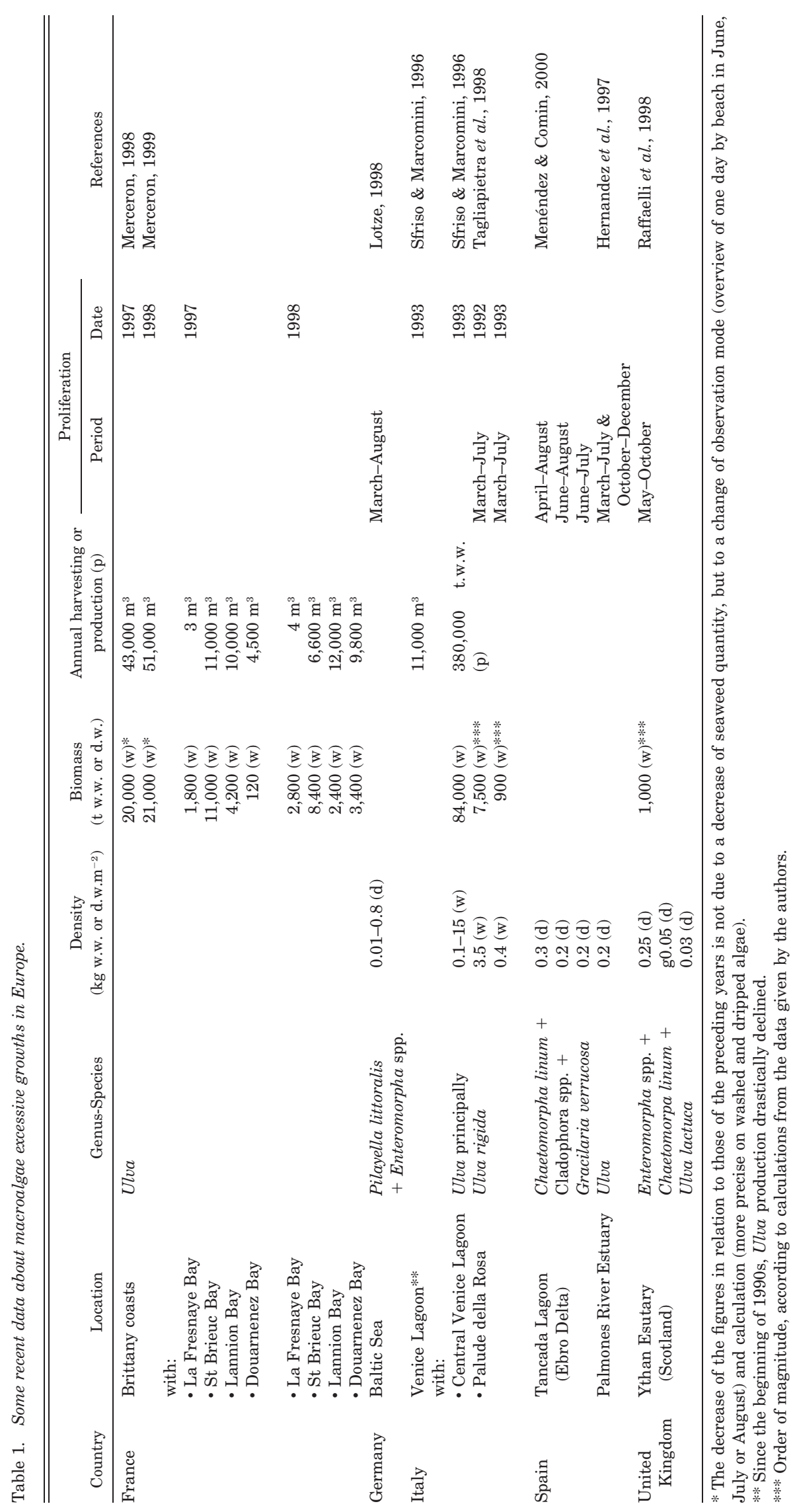




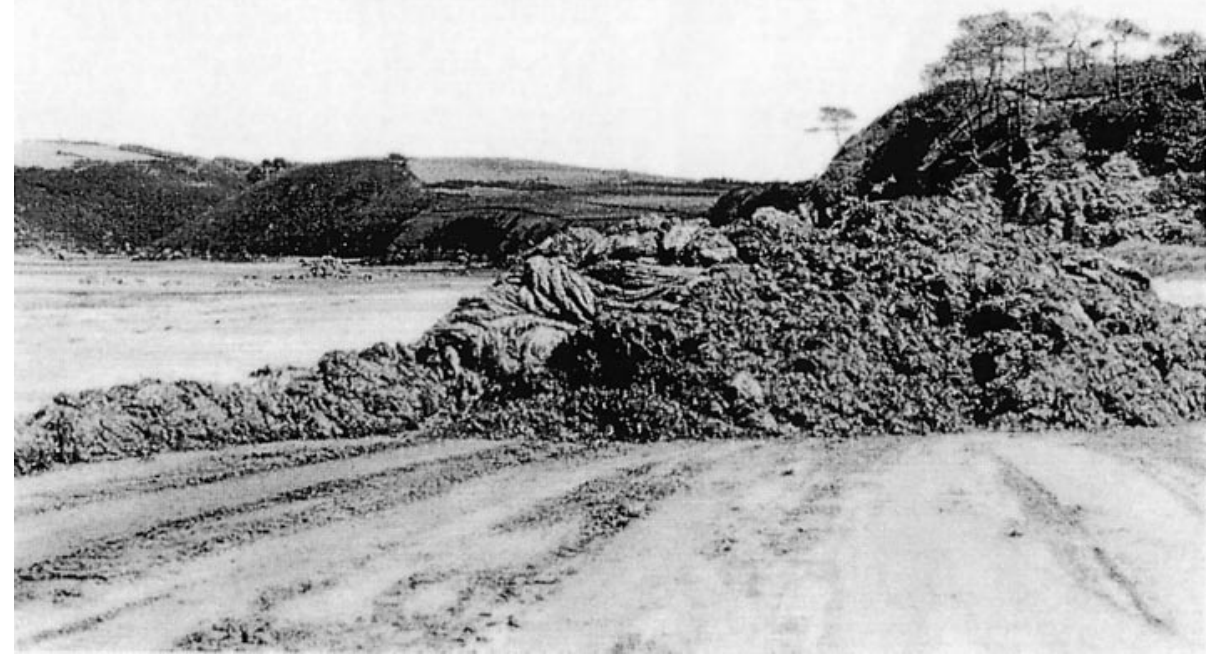

Figure 2. Ulva collect in Hillion Bay (Brittany, France). Harvesting is made with loaders, resulting in the collection of a heterogeneous mixture of seaweed and sand.

often considered to be positive. In some cases, seaweed proliferations provide a supplementary food source which can have a favourable effect on the development of herbivores. Another significant ecological role of excessive growths of algae is the provision of habitats and refuges against predators. For instance, LENANTON et al. (1985) noted that an increase in fish catches followed an increase in the biomass of Cladophora and Chaetomorpha, while VIRnsteIn and CARBONARA (1985) reported high densities of small animals (peracarid crustaceans, gastropod molluscs, etc.) in Gracilaria drift beds. These proliferations do, however, pose significant fouling problems in aquacultural areas.

Moreover, the seaweeds involved in the proliferations appear not to be very numerous in terms of species, but represent a stronger proportion of the algal community, with the growth being selective according to their degree of tolerance of pollution and to their affinity for the nutrients. The most sensitive species regress in quantity or disappear in favour of more tolerant species. In Norwegian fjords, the competition for substrata and the screen effect caused by algal deposits strongly reduce thus the chance of development for the original populations of Ascophyllum nodosum (LOBBAN et al., 1985).

When seaweed is washed ashore or when degradation begins, the problem of proliferation is stated in terms of pollution. The significant quantities of $\mathrm{N}$ and $\mathrm{P}$ coming from the decomposition of deposits maintain a state of eutrophication.

The decomposition of algae leads to the production of toxins, and the oxidation of the organic matter creates anoxic conditions, which, favoured by the low rate of renewal and the stratification of water, can result in the death of benthic animals (JOHNSON and WELSH, 1985). In aquaculture areas, the decomposition of the algae leads to the death of shellfish; in some fishing grounds, a reduction in catches is observed. For example, in the south-east Kattegat (Sweden), the mass occurrence of macroalgae in nearshore areas in 1980 was fol- lowed by the death of fish and, in shallow waters, by mass mortality of bivalves (ROSENBERG et al., 1990).

The accumulation of rubbish alters the actual nature of the sediment, sometimes transforming a sandy sediment into organic mud. The removal of the cast seaweed also causes considerable exports of sediment, the equipment employed (such as public loaders) not being very selective (BRAULT and GOLVEN, 1983) (Figure 2). For Lannion Bay alone, exports of sand are estimated at approximately 500 tonnes per season. The impact of such traffic (2000 truck arrivals and departures) and such removals, in hydrological and ecological terms, has not yet been determined. In Peel Inlet, Western Australia, it was noted that the loaders compacted the sediment, beach sand was picked up with the algae, and rushes, which stabilise the foreshore, were destroyed, resulting in erosion and receding of certain beaches by approximately 10-12 m based on observations spanning over seventeen years of beach cleaning (AtKINs et al., 1993).

Another pollution comes from the fermentation of sulphured polysaccharides, which liberates significant quantities of hydrogen sulphide into the atmosphere, and thus bothers the inhabitants and tourists in the regions affected (BRIAND, 1989). Hydrogen sulphide production was estimated at $95,000 \mathrm{~m}^{3}$ in the city of Tunis (Tunisia), when significant excessive growths occurred in the lagoon, the average concentration in the atmosphere reaching $3 \mathrm{ml} \mathrm{H}_{2} \mathrm{~S} \mathrm{~m}^{-3}$ (STIRN, 1968). Moreover, chironomids form clouds and are favoured by their tolerance of anoxic conditions and a temporary disappearance of zoobenthos and fish (CERETTI et al., 1985). BouRGuÈs (1992), referring to Arcachon Bay, mentioned that the chironomids strongly appear during the algae decay and take part in the fragmentation of plant material.

\section{Causes}

Among the different elements of the biotope which can be involved in the excessive growth of algae (light, temperature, 
substratum, depth, salinity, turbidity, water motion, ...), the presence of nutrients in excess is essential: a minimum quantity is required for algal proliferation, sensibly $0.1-0.2 \mathrm{mg} \mathrm{l}^{-1}$ of inorganic nitrogen and $0.02-0.03 \mathrm{mg} \mathrm{l}^{-1}$ of inorganic phosphorus (HoDGKIN et al., 1980). Generally, unlike freshwater systems which are, principally, phosphorus limited, marine waters are mostly nitrogen and, sometimes, iron limited (Ménesguen and Piriou, 1995; Sequi et al., 1992). The unusual P limitation in most cases of eutrophication in bodies of marine water of Western Australia is explained by the nature and use of the soils, as well as meteorological conditions (HodGKIN and Yeates, 1993).

The main anthropogenic source of nitrogen is primarily agricultural, as on the coasts of Brittany (BRIAND, 1989), in the Venice Lagoon (SFRIso et al., 1992), or in Peel Inlet (HoDGKIN et al., 1980). Conversely, the influence of agriculture on the marine environment is generally due to nitrogen and not to phosphorus: the N/P ratio in waters coming from soil drainage usually ranges from 10 to 1000 (SEQUI et al., 1992). Nitrogen inputs from rivers and of atmospheric origin may be of the same order of magnitude (THYBO-CHRISTESEN et al., 1993). Phosphorus, on the other hand, is trapped in the sediment from year to year. In the Venice Lagoon, the $\mathrm{P}$ and $\mathrm{N}$ concentrations in the top $5-10 \mathrm{~cm}$ of sediment have increased by a factor up to 30 and 2.4 respectively from 1948 to 1968 (SFriso et al., 1992). Finally, recycled nutrients are a major source for primary production, the recycling reaching values on the order of $60-65 \%$ for $\mathrm{N}$ and $50-65 \%$ for $\mathrm{P}\left(\mathrm{GA}_{\mathrm{A}}\right.$ BRIELSON et al., 1983; THYBO-CHRISTESEN et al., 1993). In countries with intensive marine fish farms, such as Norway, Japan, or Philippines, aquaculture also contributes a significant quantity of nutrients by way of residual feed and excrements from fish, which, moreover, form nutrients-rich sediments in confined areas.

Nevertheless, the phenomenon is all the more remarkable when concomitance exists between the problem of eutrophication and the particular environmental conditions (winds, currents, weak rate of water renewal, etc.). Thus, the actual lagoon configuration facilitates the trapping of nutritional salts and chemical wastes. Lagoons, generally shallow, also allow rapid water warming and significant photosynthetic activity. In an open sea, an extensive intertidal sandy area with gentle slope, a supply of fresh water with sufficient nutrient flows, and very slight residual tide water circulation resulting in a sea water trapping situation encountered in the lagoons, are necessary for the occurrence of "green tides" (PIRIOU et al., 1991).

A reduction in photosynthesis may be a cause of limitation of the seaweed proliferations. It can occur when light is too low. It also occurs, for instance, when there is light attenuation by shading by other algae (macro or micro) or cyanobacteria, as described in the Peel-Harvey system (LAVERY et al., 1991). In the Venice Lagoon, SFRIso and PAVONI (1994) showed that when macroalgae were absent, it was mainly due to the particulate matter content, which, in forming a deposit on the bottom algae, prevented their growth. Conversely, LEVAVASSEUR (1986) has shown that strong and long periods of light result in the destruction of the chlorophyll pigments of Ulva. In Brittany, a comparison between 'green tides' in the Bays of Saint-Brieuc and Lannion provided some evidence of a limitation in the photosynthetic rate (LE BOzEC, 1993). The growth halts each year at the beginning of Summer. It seems to be due, essentially, to a loss of the photosynthetic capacity of the alga, the Ulva of 'green tides' being particulary sensitive to light (PIRIOU and DuvaL, 1990).

\section{Impact on the Local Economy}

The decrease in phytoplankton in shellfish cultivation areas, the increase of nutrients linked with dystrophic crises resulting in 'red tides', the difficulty of access to beaches, the presence of seaweed in water, as well as the production of nauseating hydrogen sulphide stemming from the accumulation and decomposition of green seaweed, are particularly troublesome with sometimes ensuing significant financial effects.

Some communities, therefore, undertake systematic collection of the algae, a very costly undertaking. In France, at the end of the $1980 \mathrm{~s}$, it cost, from FFR 50 to 800 ( $1 \mathrm{FFR}=0.15$ $€)$ per tonne collected, depending on the type of machine used and the area affected (BRIAND, 1991). In Peel Inlet, the cost was estimated at 230,000 AUD annually ( 1 AUD $=0.55$ USD) for $13,000 \mathrm{~m}^{3}$ of algae, $90 \%$ of which was removed from the beaches (ATKINs et al., 1993). In Brittany, harvesting was undertaken in the Bays of Saint-Brieuc and Lannion (department of the Côtes du Nord, now Côtes d'Armor). This was considered to be too expensive (it had cost $670,000 \mathrm{FFR}$ in 1972-KOPP, 1977), and harvesting was reduced until the 1980s when it was resumed. In 1986, the cost exceeded one million French francs for this department alone (BRIAND, 1989). It increases regularly: 1.6 million francs for the whole of Brittany, for 46,000 $\mathrm{m}^{3}$ harvested, in 1987; 3.2 for 98,000 $\mathrm{m}^{3}$ in 1991; 3.6 for $90,000 \mathrm{~m}^{3}$ in 1992 (CEVA, 1993). Forty five percent of the districts along the Brittany coast are obliged to remove mechanically the green algae from their beaches (DION, 1994). The cast seaweed is then spread in fields as a fertilising agent, or piled in dumps. In the Orbetello Lagoon (Italy), because of the economical importance of fishing in the lagoon, Chaetomorpha linum is harvested to prevent anoxia, such as that reported in the Venice Lagoon, and to promote the life of the fauna, fish and crustaceans. In $1988,1480 \mathrm{t}$ w.w. were collected at a cost of 36.5 million lire $(1000$ ITL $=1 €)$, representing $15 \%$ of the seaweed in an area of 290 ha, covered by an average of $3.4 \mathrm{~kg} \mathrm{~m}^{-2}$ (ORLANDINI, 1988).

As the systematic collection of the algae is often insufficient, restoration measures are usually necessary. Some concern change in agricultural practices and waste water management. Others are directly related to the eutrophicated water body and their costs may be clearly attributed to the fight against seaweed proliferation. Thus, the construction of the Damesville Channel from the Harvey Estuary to the sea, designed to reduce the phosphorus concentration in Peel Inlet, is estimated at $60.10^{6} \mathrm{AUD}$, which gives an idea of the social concern for the welfare of the estuary (HODGKIN and HAMILTON, 1993). 


\section{INVASION OF ECOSYSTEM BY SEAWEED}

The phenomenon of proliferating algae is fundamentally different from that of invasive algae, such as Sargassum muticum (Yendo) Fensholt (Belsher and Boyen, 1983; CRITCHLEY et al., 1990) or Caulerpa taxifolia (Vahl) C. Agardh (MEINESZ et al., 1993), the excessive growth of the latter resulting from the introduction of the alga into waters where it has no predator. In the case of Caulerpa taxifolia, for the most part, the sites colonized are typical of unpolluted environments (BELSHER et al., 1994).

Nevertheless, it is sometimes difficult to say to what extent each of the phenomena is involved. The introduction of foreign species, capable of taking advantage of coastal water pollution, may result in changes to the local vegetation. For instance, in Japan, Ulva fasciata, stimulated by chemical factors, and supported by vigorous propagation, has supplanted the indigenous dominant species Ulva pertusa Kjellman (ARAZAKI, 1984). BACH and JOSSELYN (1979) envisaged two alternative hypotheses for excessive growths of Cladophora prolifera, which occured in Bermuda. It could be either an invasive or opportunist alga, the increase in the concentration of nutrients due to human activity being the cause of the proliferation. Finally, LAPOINTE and O'CONNELL (1989) showed that the spread of the alga through Bermuda's inshore waters was clearly related to the enrichment in nutrients over the past 20 years. The opportunistic seaweed Gracilaria tikvahiae, which now proliferates in Waquoit Bay (Massachussets) or in Rhode Island, was not noted as being present in earlier studies concerning these zones (PECKOL et al., 1994).

\section{PROLIFERATING SEAWEED AND CORAL REEFS}

WILKINSON (1996) estimates that $30 \%$ of coral reefs are doomed, and $30 \%$ are seriously threatened, with only $40 \%$ being safe.

It seems obvious that the main factor responsible for this state is human pressure on a local scale, rather than global change, although global warming and depletion of ozone may be involved (DuBINSKY and StAMBLER, 1996). Coral is adversely affected by elevated nutrient levels, but the effect could be indirect. The zooxanthellae, photosynthetic dinoflagellate symbionts of the corals, are less efficient than seaweed for catching the nutrients. In all cases when corals were overgrown by algae, their eventual death results from the combination of shading, night-time depletion of oxygen due to impeded circulation, and toxins, notably $\mathrm{H}_{2} \mathrm{~S}$, from the decaying algae and anoxic sediments.

MARSZALEK (1981), in a review of the effects of sewage effluents on the coral reefs, concluded that the most serious damage resulted from competition with high-nutrient stimulated algae, rather than from effluent toxicity. Recent examples of these phenomena have been described for the Red Sea reefs at the Eastern Sinai Peninsula (RIEGL and VELIMIROV, 1991), or in the Gulf of Aqaba, where the green seaweed Enteromorpha sp. smothered the corals during cold winters (GENIN et al., 1995), and for Mauritius (Indian Ocean), with the development of an important belt of the free floating alga Ulva reticulata (beds up to $30-50 \mathrm{~cm}$ in thickness) in all the outer zone of the reef in the vicinity of the sewage outfall (THOMASsin et al., 1998).

LAPOINTE (1997) mentioned the unusual growth of macroalgae in Florida and in Jamaica as a serious danger for the coral reefs. HuguEs et al. (1999) argued that macroalgal blooms on reefs in these places were controlled by the decrease in fishes (overfishing) and sea urchins (die off). During the past decade, however, macroalgal blooms (Chaetomorpha linum notably) have become increasingly common on Jamaican reefs adjacent to nutrient input from seawage or agricultural runoff (LAPOINTE, 1999). The term 'macroalgal bloom' is used here only to indicate an increase in abundance. So, even if the mechanism is probably similar to this one leading to the excessive growth, and reported for this reason, the scale of the phenomenon is not the same.

\section{THE BLACK SEA CASE}

In the Black Sea, the exchange rate with the ocean is very low, the communication with the Mediterranean Sea being restricted. A great part of the polluting load comes from agriculture (CADDY and GRIFFITHS, 1996). The retention of the water masses near the coast could then have significant consequences on the macro-algal population. In actual fact, attention is rather focused on phytoplankton and its relationship with the invasion of the comb jelly Mnemiopsis leidyi and the decrease of the fish stocks (FAO, 1996; LANCELOT et al., 2002). No excessive growth of seaweed were reported until recently, even if such phenomena were mentioned in harbor sites, but at a low extent (CELAN and BAVARU, 1977), and observed, it seems, more recently at a more significant scale (VERSHININ and KAMNEV, 2001; Frangopol, personal communication). Moreover, the disappearance of Cystoseira barbata was reported for the Vama Veche site (Romania), substrata being now colonized by opportunistic algae such as Enteromorpha, Ulva, Cladophora, etc. (PetRANU et al., 1999).

Nevertheless, some conditions seem to be favorable to the proliferations: numerous authors consider the Black Sea as an eutrophicated sea (Konovalov and MurRAy, 2001). The low salinity of the water gives generally an advantage to opportunistic green algae. The presence of slight slopes and lagoons, combined with lack of tide, is another element. Similarly, the metal concentrations inside Ulva rigida encountered along the Turkish coasts and Ulva spp., which develop in Brittany, are very similar (BRIAND, 1989; TOPCUOGLU et $a l$., 2002). Conversely, the existence of an anoxic area in depth, which traps the nutrients and is the place of biochemical transformations, the occurrence of contrasted temperatures, the presence of sediments are unfavourable conditions.

Another question is the ratio between the different elements (N/P/Si). As significant phytoplankton biomass was reported (Moncheva et al., 2001; GARNIER et al., 2002), it seems that this ratio is such that micro-algae develop rather than macro-algae when an anthropogenic supply of nutrients is excessive. The question of the changes brought by the Danube damming can be evolutive, the first effect having been to decrease the diatom population, by retaining silicates (TURKEY, 1999). At Constantza station (Romania), the N/P ratio was larger in 1997 (molar ratio $=17$ ) than during all the 
preceding years since 1980, from when it was measured, and it followed a rising curve (CocIAsu et al., 1998). Phosphorus would become a limiting factor for phytoplankton, and macroalgal "blooms" could occur.

\section{EVOLUTION OF PERTURBED ECOSYSTEMS}

Ecosystems touched by excessive growth of seaweeds were followed for decades. Each one is a special case, because all differ in their natural environment, but also in the human activities and the interventions to which they were subjected. Four examples give an idea of the possible evolutions.

\section{Brittany}

In Brittany, as the nutrient supply to the sea is still increasing, the number of locations where green tides develop is also increasing from year to year, even if the biomass was not increased inside well-installed locations. The duration of the presence of Ulva mass on beaches becomes longer and longer; in some places like the Bay of La Fresnaye, it tends now to stay year-round instead of only during spring and summer. Another way of development of green tides is seawards. In some sites where the algal proliferation appeared for several decades (bays of Douarnenez, Concarneau, Lannion, Saint-Brieuc), drifting Ulva deposited on the bay's bottom can be observed seawards up to 20 meter depth. Its density range is from nil to several kg.m ${ }^{-2}$ wet weight; the latter case displays an endless green carpet put on sand. Globally this "offshore" biomass frequently exceeds that of the "nearshore" one which is the only one, till now, that has been quantified.

A program to remove phosphorus from the waste waters of the towns was enforced, yet had no effect on the excessive growths of seaweed, the limiting factor being nitrogen in Brittany coastal waters.

Without reduction of the nitrogen supply to the sea and/or nitrogen outputs from agriculture, the situation will worsen, with annual variations caused by temperature, irradiance, and river flow conditions.

\section{Tunis Lagoon}

In contrast, a decrease in the macroalgal biomass and a change in its composition were observed following a reduction in the concentration of nutrients as a result of environmental restoration measures. In the Lagoon of Tunis, total $\mathrm{N}$ and $\mathrm{P}$ concentrations decreased, on average, from about $4000 \mu \mathrm{g}$ $\mathrm{L}^{-1}$ to 1000 , then to 400 , and $600 \mu \mathrm{g} \mathrm{\textrm {L } ^ { - 1 }}$ to 100 , then to 20 respectively. Waste water discharge into the lagoon was suppressed in 1981. In 1987, water circulation in the lagoon was improved by building a sea wall separating the lagoon into two parts, the macroalgae being restrained to the shallow (1 $\mathrm{m})$ southern part. Following this change, the Ulva biomass decreased from about 12,000 t w.w. annually to 3600 in 1989 and proliferation stopped in 1990, whereas Chaetomorpha became the dominant species (4200 $t$ in 1989,5600 in 1990) and Gracilaria appeared (BEN CHARRADA, 1992).

\section{Venice Lagoon}

The Venice Lagoon may be considered as an unstable system. Nutrients come from agriculture and numerous industrial plants. Harvesting of Gracilaria and fishing were traditional. Collecting of Ulva was introduced, when this alga began to be really troublesome. Boat circulation inside the lagoon is significant. Hydraulic changes and nutrient inputs led, from the '60s, to an abnormal growth of Ulva rigida, whose biomass degradation caused frequent anoxic crises, the decrease of the biomass of seagrasses, and the disappearance of many seaweeds unable to tolerate dystrophic conditions. Starting from the '90s, a strong reduction of Ulva was observed, leading to a partial repopulation of the marine phanerogams, phenomenon limited by the harvesting of Tapes philippinarum, a bivalve introduced in the lagoon for economic purposes, with dredges which resuspended the sediments. Moreover, non-indigenous species, such as Sargassum muticum, Undaria pinnatifida, or Grateloupia doryphora, spread all over the lagoon (CALICETI et al., 2002). SFRISO and PAVONI (1994) had stressed the recent and unusual phytoplankton blooms, due to the sedimentation of particulate matter re-suspended from the bottom sediments, which then covered the macroalgal fronds.

\section{Peel-Harvey Estuarine System}

In most cases in Western Australia the sandy soils are unable to retain phosphorus and the applied dose $\left(18 \mathrm{~kg} \mathrm{ha}^{-1}\right.$ $\mathrm{y}^{-1}$ ) is adapted to newly clean land and not to developed land; the rains at the end of the dry season leach the mineralised nutrients, and the fertilisers added by farmers before the rains make the soils unworkable (HoDGKIN and HAMILTON, 1993). Thus $\mathrm{N}$ and $\mathrm{P}$ both come, in solution, in the drainage waters from the coastal plain catchment and $\mathrm{N}$ is limited in marine embayments only when there is little drainage from the land.

The Peel-Harvey estuarine system, $80 \mathrm{~km}$ south of Perth, has been particularly well studied because of the trouble caused by eutrophication in this residential and recreative area (HodGKIN et al., 1980). The Harvey Estuary and Peel Inlet are two basins subjected to cyanobacterial blooms and macroalgae proliferations respectively. The problem is recent, and results from a large increase in nutrients input into the estuary. In Peel Inlet, seaweed growth and drifting onto the beaches has necessitated harvesting (МсСомв et al., 1981). The biomass almost exclusively comprises four genera of green algae, viz. Cladophora, Chaetomorpha, Enteromorpha, and Ulva, each one having been dominant in turn with 50,000 t d.w. in 1979 of Cladophora, 18,000 t in 1981 of Chaetomorpha, 15,000 t in 1984 of Enteromorpha, and 14,000 t in 1985 of Ulva (LAVERY et al., 1991). Events which caused the changes vary in nature and include a storm, a cyanobacteria bloom in Harvey Estuary leading to a light attenuation in Peel Inlet, temperatures, irradiance levels, flow of the rivers, and change in the nutrient rates.

Comparing two similar beaches in the Peel-Harvey estuarine system, where accumulations of macroalgae occur, LAVERY et al. (1999) noticed that, in the long-term, the beach, where harvesting was performed for 1974, had a macro-in- 


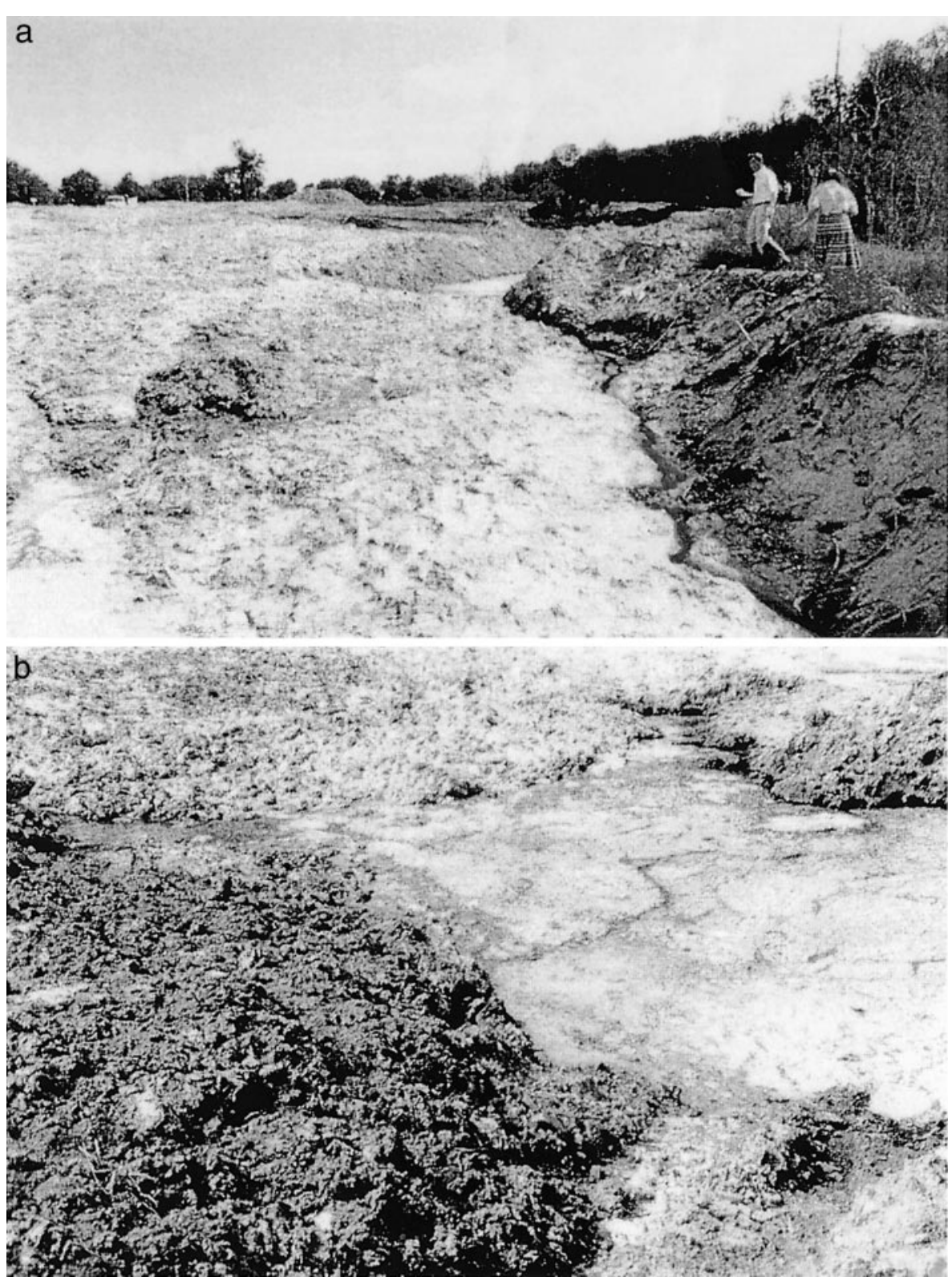

Figure 3. (a) Stranded Ulva dump near Hillion (Brittany, France): General view showing the scale of the dump and, in the back, a composting pile of a mixture of seaweed and straw, the pile keeping its initial height, contrary to the seaweed which liquefies and spread out. (b) Stranded Ulva dump near Hillion (Brittany, France): Close view showing the release of juice by the liquefying seaweed.

vertebrate assemblage similar to that of another similar beach in which macroalgae did not accumulate. The beach where stranded seaweeds were not removed had a different faunal assemblage. Moreover, the short-term effects of the harvesting were only temporary.

\section{SUSTAINABILITY}

\section{General Principles}

Eutrophication is certainly a risk for numerous coastal ecosystems, due to agricultural and industrial human activities, and to domestic waste waters. To this risk, add the foreseeable climate changes. Under such conditions, it is necessary to define criterions in order that an ecosystem may be considered sustainable.

Sustainability does not involve a return to the initial state, but rather a maintenance in an equilibrium state, where a sufficient biodiversity is compatible with the durability of the ecosystem, and where the human functions which are assigned to it (production, recreation, environment) may be assumed. The economics also intervene, because the cost/benefit ratio should be favourable or neutral. Subjective criteria 
are inescapable: what are we ready to accept? The first thing to define then is a sustainable acceptable ecosystem.

The second thing to be taken into account is the probability of evolution towards something which is or is not an acceptable ecosystem. Therefore it is necessary to anticipate. The climate changes should be considered, especially when invasive species, opportunistic or not, vegetal or animal, are involved.

The means at our disposal are preventive or curative. In the field of prevention, it is sometimes difficult to be understood, because the fight against some causes of eutrophication involves many people. A program should be very exhaustive, and the approach integrated. For instance, it is known that the atmospheric fallouts of nitrogen in an ammoniacal or oxidized form in a closed water body may be of the same order of magnitude than the nitrogenous loadings coming from the streams (CORPEN, 2001). This consideration has to be translated into a reduction of nitrogen compounds release at the source.

In the field of remediation, things are sometimes easier, but often costly. Solutions include hydrology, bioremediation, harvesting, and treatment of waste. Storage in a dump is unacceptable because it leads to a recycling of nutrients (Figure 3$)$.

\section{Proposals}

The most avanced plan concerns Western Australia (HoDGKIN and YeATES, 1993). Emphasis has been placed here on phosphorus (but a number of measures concern the reduction of both $\mathrm{N}$ and $\mathrm{P}$ ), although the lowering of $\mathrm{P}$ load alone may result, for a time, in an increase of seaweed proliferation by clearing the water and favouring some species. Siliceous, acidic, sandy-surfaced soils, with an extremely low clay and colloidal content have a very low $\mathrm{P}$ retention capacity: 20 to $200 \mu \mathrm{g} \mathrm{g}^{-1}$ for $70 \%$ of the soils of the basin areas. Considerable research has been carried out (i) on enrichments suitable for their improvement, leading to a push for the use of bauxite processing residues, (ii) to develop "slow release sources" of phosphorus, agronomically and economically effective, in order to replace superphosphate. The programme includes many other measures in the framework of a long term strategy: - using rational fertilisation and alternative farming systems, which would be beneficial to both farmers and the general community, -replacing shallow-rooted annual plants with deep-rooted agricultural or forestry species, protecting the remaining indigenous vegetation, - planting trees, notably Eucalyptus globulus, in strategic blocks, modifying the coastal plain drainage system and the river banks, building flood detention reservoirs, - preserving and improving natural wetlands, - and, finally, processing the point sources (pigsties, sheep farms, intensive poultry farms, slaughterhouses, sewage treatment works, domestic gardens and public open spaces).

In Brittany, a better knowledge of the conditions of their development has led to measures proposed according to the sites concerned (PIRIOU et al., 1993). As the nitrogen input residence time is two to five days on the sensitive coastal sites, principal flows of late spring and early summer are to be reduced. Inland, granite soils are characterised by relatively regular water and nitrogen fluxes, due to the buffer role of the groundwater loaded by the nutrient surplus; schistose soils are non-permeable. In the first case, rigorous fertiliser management is recommended; in the second, an improvement of the streams (afforestation, etc.) in order to cut back the spring rises in the water level. The development of the wetlands is also proposed to improve the actual purification of the streams.

Because it is fragile due to supplies of fresh water that may be loaded with nutrients, pesticides, chemicals, and metals, the Black Sea is the object of programs such as the NATO TU-Black Sea Project (BARBour, 1997), an environmental program on the Danube River Basin (BotTERWEG and RoDDA, 1999), and EROS 21 (LANCELOT et al., 2002). Each of the programs recommends the decrease of nutrient discharge, but no one can be sure of the real impact of the advocated measures. The question of excessive growth of opportunistic seaweed is not envisaged in those programs, but they can be avoided, unless climate warming and change in the nutrient range act contrary to that.

\section{CONCLUSION}

Algae seem thus to be simultaneously a scourge and a resource. Eutrophication problems have become a matter of major concern even if the phenomenon is far from being a new development. It has been necessary to cope with it for more than a quarter of the last century. Its management is neither a simple nor a cheap task. Doubtlessly a good deal of the problem is due to anthropic causes and constitutes an important part of the efforts to reach efficient integrated coastal zone management (CHARLIER and LONHIENNE, 1996).

Removal of algae requires manpower and equipment, neither of which comes cheaply. The idea of utilization of the algal biomass, and of avoiding its discharge on dumps, also costly, has been courted for some time: uses in food, fodder, medicine, pharmacy, cosmetology, agriculture, and others have been brought forth, tested but often stumble against pre-conceived positions, even myths, customer resistance, and economics.

Succesful implementation of management programmes concerning the decrease of the nutrients at the source will be long and difficult, with scientific, social and political implications. It is however the necessary condition for a really sustainable development.

\section{ACKNOWLEDGMENTS}

The authors wish to thank Yves Picard for assistance in producing the figures. They are very grateful to Roger $\mathrm{H}$. Charlier for having checked the English language of the manuscript.

\section{LITERATURE CITED}

ARAZAKI, S., 1984. A new aspect of Ulva vegetation along the Japanese coast. Hydrobiologia 116/117, 229-232.

AtKins, R.P.; DeEley, D.M., and McAlpine, K.W., 1993. Managing the aquatic environment. Fertilizer Research, 36, 171-175. 
Auby, I.; Manaud, F.; Maurer, D., and Trut, G., 1994. Etude de la prolifération des algues vertes dans le bassin d'Arcachon. Rapport IFREMER-CEMAGREF-SSA-SABARC, 163p.

BACH, S.D. and Josselyn, M.N., 1979. Production and biomass of Cladophora prolifera (Chlorophyta, Cladophorales) in Bermuda. Botanica Marina, 22, 163-168.

BARBOUR, D.K., 1997. The NATO TU-Black Sea project workshop. Ocean, Atmosphere and Space, S\&T Newsletter 24.

Belsher, T. and Boyen, C., 1983. Sargassum muticum (Yendo) Fensholt: une sargasse parmi d'autres. In: Les Végétaux aquatiques. Biomasse Actualités, 12 (Suppl. 3): 13.

Belsher, T.; Youenou, G.; Dimeet, J.; Raillard, J.M.; BerTRAND, S., and MÉREAU, N., 1994. Cartographie et évolution de Caulerpa taxifolia (Alpes maritimes et Principauté de Monaco; année 1992). In: Boudouresque, C.F.; Meinesz, A., and Gravez, V. (eds) Proceedings of the First International Workshop on Caulerpa taxifolia. Nice 17-18/01/1994. G.I.S. Posidonie Publications, Marseille, France, p.147-154.

Ben CharradA, R., 1992. Le lac de Tunis après les aménagements. Paramètres physico-chimiques de l'eau et relation avec la croissance des macroalgues. Marine Life, 1, 29-44.

BotTerweG, T. and RodDA, D.W., 1999. Danube River Basin: progress with environemental programme. Water Science and Technology, 40(10), 1-8.

BourguÈs, S., 1992. Contribution à l'étude de la dégradation de l'algue verte: Ulvaria obscura (Kützing). Rôle des bactéries anaérobies hétérotrophes (bactéries sulfato-réductrices et fermentatives). Mémoire de D.E.A: Environnements océaniques actuels, $\mathrm{Pa}$ léoclimatologie et Paléo-océanographie. Univ. Bordeaux I, France, $30 \mathrm{p}$.

Brault, D., 1983. Les ulves. Epuration du milieu. In: Les végétaux aquatiques. Biomasse Actualités, 12 (Suppl. 3), 14.

Brault, D. and Golven, P., 1983. Techniques de récolte des algues vertes. In: Les Végétaux aquatiques. Biomasse Actualités, 12 (Suppl. 3), 26.

BRIAND, X., 1989. Prolifération de l'algue verte Ulva sp. en baie de Lannion (France): étude d'une nuisance et de son traitement par fermentation anaérobie. Thèse de 3ème cycle: Biologie et Physiologie Végétale. Univ. Lille I, France. VII + 210p.

BRIAND, X., 1991. Seaweed harvesting in Europe. In: GUIRY, M.D. and Blunden, G. (eds) Seaweed Resources in Europe: Uses and Potential. Chichester, UK: Wiley, pp. 259-308.

CADDY, J.F. and GRIFFiths, R.C., 1996. Les ressources vivantes et leur développement durable: quelques perspectives environnementales et institutionnelles. FAO Document technique sur les pêches, 353, 174p.

Calicetti, M.; Angese, E.; Sfriso, A., and Pavoni, B., 2002. Heavy metal contamination in the seaweeds of the Venice Lagoon. Chemosphere, 47, 443-454.

Casabianca-Chassany, M.L. (de), 1992. Method for evaluating algal production and degradation based on nitrogen levels in particular organic matter. Bioresource Technology, 39, 1-7.

CElan, M. and BAvaru, A., 1977. Sur une population de l'Enteromorpha linza (L.) J. Agardh du port de Tomis (Constantza). Rev. Roum. Biol. ser. biol. végét., 22, 33-36. (Ed. Acad. RSR, Bucuresti, Romania).

Ceretti, G.; Ferrarese, U., and Scattolin, M., 1985. I chironomidi nella Laguna di Venezia. Arsenale, Venice, Italy, 59p.

CEVA, 1993. Marées vertes: les traitements curatifs. Document du CEVA. CEVA (Centre d'Etude et de Valorisation des Algues), 22610 Pleubian, France, 14p.

ChARLIER, R.H. and LonHIEnNe, T., 1996. The management of eutrophicated waters. In: Schramm W. and Nienhuis, P. (eds) Marine benthic vegetation. Recent changes and the effects of eutrophication. Berlin: Springer Verlag, pp. 45-78.

Cociasu, A.; Popa, L., and Buga, L., 1998. Long-term evolution of the nutrient concentrations on the north-western shelf of the Black Sea. Cercetari Marine, 31, 13-29. (IRCM, Constantza, Romania).

CORPEN, 2001. Les émissions d'ammoniac d'origine agricole dans l'atmosphère. Etat des connaissances et perspectives de réduction des émissions. Document $d u$ CORPEN. Ministère de l'aménagement du territoire et de l'environnement, 75007 Paris, France, 110p.

Critchley, A.T.; FArnham, W.F.; Yoshida, T., and Norton, T.A., 1990. A bibliography of the invasive alga Sargasum muticum (Yendo) Fensholt (Fucales, Sargassaceae). Botanica Marina, 33, 551562.

Difz Pifferez, M. and Lopez, H., 1959. Taxonomia, ecologia y valor nutrimental de las algas marinas cubana. Instituo cubano de investigaciones. Technologicas. Serie de estudios sobre Trabajos de investigation, 6, 37-39.

Dion, P., 1994. Present status of the Ulva mass blooms on the Brittany coasts. In: Delépine, R. and Morand, P. (eds). Production and Exploitation of Entire Seaweeds. Proceedings of the third COST 48-subgroup 3 workshop. Paimpol-St. Malo (France). 9-14 March 1991. Commission of the European Communities, DG XII/ F Biotechnology, Brussels-Biogéographie et Valorisation des Algues, Univ. Paris VI, France, pp. 34-36.

FAO Fisheries Department, 1996. Fisheries and aquaculture in Europe: situation and outlook in 1996. FAO Fisheries Circular 911. $54 \mathrm{p}$.

Gabrielson, J.O.; Birch, P.B.; Dolin, K.S., and HAMel, D.K., 1983. Decomposition of Cladophora. II. In vitro studies of nitrogen and phosphorus regeneration. Botanica Marina, 26, 173-179.

Garnier, J.; Billen, G.; Hannon, E.; Fonbonne, S.; Videnina, Y., and Soulie, M., 2002. Modelling the transfer and retention of nutrients in the drainage network of the Danube River. Estuarine, Coastal and Shelf Science, 54, 285-308.

Genin, A.; LAZAR, B., and Brenner, S., 1995. Vertical mixing and coral deapth in the Red Sea following the eruption of Mount Pinatubo. Nature, 377, 507-510.

Hernández, I.; Peralta, G.; PÉrez-Lloréns, J.L.; Vergara, J.J., and NiELL, F.X., 1997. Biomass and dynamics of growth of Ulva species in Palmones River Estuary. Journal of Phycology, 33, 764772 .

HodGKin, E.P. and Hamilton, B.H., 1993. Fertilizers and eutrophication in southwestern Australia: Setting the scene. Fertilizer Research, 36, 95-103.

HodGKIN, E.P. and YeAtes, J.S. (eds)., 1993. Fertilizers and eutrophication in South-Western Australia. Fertilizer Research 36(2) special issue, III-76p.

Hodgkin, E.P.; Birch, P.B.; Black, R.E., and Humphries, R.B. 1980. The Peel-Harvey estuarine system study (1976-1980). Report $n^{\circ}$ 9. Department of Conservation and Environment, Perth, Western Australia, 72p.

Johnson, D.A. and Welsh, B.L., 1985. Detrimental effects of Ulva lactuca (L.) exudates and low oxygen on estuarine crab larvae. Journal of Experimental Marine Biology and Ecology, 86, 73-83.

Konovalov, S.K. and MurRAy, J.W., 2001. Variations in the chemistry of the Black Sea on a time scale of decades (1960-1995). Journal of Marine Systems, 31, 217-243.

KopP, J., 1977. Étude du phénomène de "marée verte" affectant les baies de Lannion et de Saint-Brieuc. Rapport de synthèse. ISTPM (Institut Scientifique et Technique des Pêches Maritimes)/IFREMER (Institut Français de Recherche pour l'Exploitation de la MER), BP 70, 29263 Plouzané, France, 102p.

Lancelot, C.; Martin, J.-M.; Panin, N., and Zaitsev, Y., 2002. The North-western Black Sea: A pilot site to understand the complex interaction between human activities and the coastal environment. Estuarine, Coastal and Shelf Science, 54, 279-283.

LAPOINTE, B.E., 1997. Nutrient thresholds for bottom-up control of macroalgal blooms on coral reefs in Jamaica and southeast Florida. Limnology and Oceanography, 42, 1119-1131.

LAPOINTE, B.E., 1999. Simultaneous top-down and bottom-up forces control macroalgal blooms on coral reefs (Reply to the comment by Hughes et al.) Limnology and Oceanography, 44, 1586-1592.

LAPOINTE, B.E. and O'CONNELL, J., 1989, Nutrient-enhanced growth of Cladophora prolifera in Harrington Sound, Bermuda: eutrophication of a confined, phophorus-limited marine ecosystem. Estuarine, Coastal and Shelf Science, 28, 347-360.

LAVERY, P.; Bottle, S., and VANDERKLIFT, M., 1999. Ecological effects of macroalgal harvesting on beaches in the Peel-Harvey Es- 
tuary, Western Australia. Estuarine, Coastal and Shelf Science, 49, 295-309.

LAVERY, P.S.; Lukatelich, R.J., and McComb, A.J., 1991. Changes in the biomass and species composition of macroalgae eutrophic estuary. Estuarine, Coastal and Shelf Science, 33, 1-22.

LE Bozec, S., 1993, Cartographie des zones sensibles à l'eutrophisation; cas des côtes bretonnes. Annexe technique $n^{\circ} 9$. Analyses chimiques dans les ulves, l'eau et le sédiment de la grève de Saint-Michel (Baie de Lannion-1991). Rapport de contrat $n^{\circ} 90$ $2430460 \mathrm{DRO} / \mathrm{EL}$ et avenant $n^{\circ}$ 1. IFREMER (Institut Français de Recherche pour l'Exploitation de la MER), BP 70, 29263 Plouzané, France-CEVA (Centre d'Etude et de Valorisation des Algues), 22610 Pleubian, France, 50p.

Lenanton, R.C.J.; Loneragan, N.R., and PotTer, I.C, 1985. Blue green algal blooms and the commercial fishery of a large Australian estuary. Marine Pollution Bulletin, 12, 477-482.

LETTS, E.A. and RichARDS, E.H., 1911. Report on green seaweeds (and especially Ulva latissima) in relation to the pollution of the waters in which they occur. Royal Commission on Sewage Disposal. 7 th report, Section II, Appendix III. HMSO, London.

Levavasseur, G., 1986. Plasticité de l'appareil pigmentaire des algues marines macrophytes. Régulation en fonction de l'environnement. Thèse de doctorat d'Etat. Univ. Paris VI, France, 210 p.

Lobban, C.S.; Harrison, P.J., and Duncan, M.J., 1985. The Physiological Ecology of Seaweeds. Cambridge University Press, Cambridge, $237 \mathrm{p}$.

Lotze, H.K., 1998. Population dynamics and species interactions in macroalgal blooms: abiotic versus biotic control at different lifecycle stages. Berichte $n^{\circ}$ 303. Institut für Meereskunde, Universität Kiel. 24105 Kiel, Germany, 134-XVIp.

Lotze, H.K.; Schramm, W.; Schories, D., and Worm, B., 1999. Control of macroalgal blooms at early developmental stages: $P i$ layella littoralis versus Enteromorpha spp. Oecologia, 119, 46-54.

MALEA, P. and HaRitonidis, S., 2000. Use of the green alga Ulva rigida C. Agardh as an indicator species to reassess metal pollution in the Thermaikos Gulf, Greece, after 13 years. Journal of Applied Phycology, 12(2), 169-176.

MARSZALEK, D.S., 1981. Effects of sewage on reef corals. Proceedings of the 4th International Coral Reef Symposium Manila, pp. 18-22.

McComb, A.J.; Atkins, R.P.; BiRCH, P.B.; GoRdon, D.M., and LUKATELICH, R.J., 1981. Eutrophication in the Peel-Harvey estuarine system, Western Australia. In: Nielsen, B. and Cronin, E. (eds) Estuaries and Nutrients. New Jersey: Humana Press, pp. 323-342.

Meinesz, A.; De Vaugelas, J.; Hesse, B., and Mari, X., 1993. Spread of the introduced tropical green alga Caulerpa toxifolia in northern Mediterranean waters. Journal of Applied Phycology, 5, 141-147.

Menéndez, M. and Comín, F.A., 2000. Spring and summer proliferation of floating macroalgae in a Mediterranean coastal lagoon (Tancada Lagoon, Ebro Delta, NE Spain). Estuarine, Coastal and Shelf Science, 51, 215-226.

Menesguen, A. and Piriou, J.-Y., 1995. Nitrogen loadings and macroalgal (Ulva sp.) mass accumulation in Brittany (France). Ophelia, 42, 227-237.

Merceron, M., 1998. Inventaire des ulves en Bretagne-Année 1997. Rapport de synthèse (Study of Ulva proliferations in Brittany-Year 1997. Synthetic report). Contrat no 97/2.210 181/YC. Agence de l'Eau Loire-Bretagne, avenue de Buffon, BP 6339, 45063 Orléans, France-IFREMER (Institut Français de Recherche pour l'Exploitation de la MER), BP 70, 29280 Plouzané, France, $18+$ $\mathrm{Xp}$.

MerCeron, M., 1999. Inventaire des ulves en Bretagne-Année 1998. Rapport de synthèse (Study of Ulva proliferations in Brittany-Year 1998. Synthetic report). R. Int. DEL/99.15/Brest. Agence de l'Eau Loire-Bretagne, avenue de Buffon, BP 6339, 45063 Orléans, France-IFREMER (Institut Français de Recherche pour l'Exploitation de la MER), BP 70, 29280 Plouzané, France, $26+$ IIp.

Moncheva, S.; Gotsis-Skretas, O.; Pagou, K., and Krastev, A., 2001. Phytoplankton blooms in Black Sea and Mediterranean coastal ecosystems subjected to anthropogenic eutrophication: similarities and differences. Estuarine, Coastal and Shelf Science, $53,281-295$.

MoRAND, P. and BRIAND, X., 1996. Excessive growth of macroalgae: a symptom of environmental disturbance. Botanica Marina, 39, 491-516.

Nienhuis, P.H., 1992. Ecology of coastal lagoons in The Netherlands (Veerse Meer and Grevelingen). Vie Milieu, 42, 59-72.

ORLANDINI, M., 1988. Harvesting of algae in polluted lagoons of Venice and Orbetello and their effective and potentiel utilization. In DE WAart, J. and Nienhuis, P.H. (eds) COST 48. Aquatic Primary Biomass-Marine Macroalgae. Proceedings of the Second Workshop of the COST 48 Subgroup 3: Biomass conversion, removal and use of nutrients. Zeist-Yerseke, The Netherlands, October 2527, 1988. Commission of the European Communities, DG XII/F Biotechnology, Brussels-Division of Nutrition and Food Research, TNO-CIVO Institutes, Zeist, The Netherlands, pp. 20-23.

Peckol, P.; DeMeo-Anderson, B.; Rivers, J., Valiela, I.; MalDONADO, M., and YATES, J., 1994. Growth, nutrient uptake capacities and tissue constituents of the macroalgae Cladophora vagabunda and Gracilaria tikvahiae related to site-specific nitrogen loading rates. Marine Biology, 121, 175-185.

Petranu, A.; Apas, M., Bodeanu, N.; Bologa, A.S.; Dumitrache, C.; Moldoveanu, M.; Radu, G., and Tiganus, V., 1999. Status and evolution of the Romanian Black Sea coastal ecosystem. In Besiktepe, S.T.; UnlÜAtA, Ü., and Bologa, A.S. (eds) Environmental Degradation of the Black Sea: Challenges and Remedies. NATO Science Series. 2. Environmental Security. Vol. 56. Kluwer Academic Publishers. Dordrecht/Boston/London. The Netherlands, pp. 175-195.

PIRIOU, J.-Y. and Duval, V., 1990. Photosynthèse et nutrition carbonée chez Ulva sp. Document DRO.EL $n^{\circ}$ 90.31. IFREMER (Institut Français de Recherche pour l'Exploitation de la MER), BP 70, 29263 Plouzané, France, XI-13p.

Piriou, J.-Y.; Menesguen, A., and Salomon, J.-C., 1991. Les marées vertes à ulves: conditions nécessaires, évolution et comparaison de sites. In: ElLiott, M. and Ducrotoy, J.-P. (eds) Estuaries and Coasts: Spatial and Temporal Intercomparisons. Proc. ECSA 19 Symposium. Olsen \& Olsen, Fredensborg, Denmark, pp.117121.

Piriou, J.-Y.; Mérot, P.; JÉGou, A.-M.; Garreau, P.; Yoni, C.; WAtremez, P.; Urvois, M.; Hallegouët, B.; Aurousseau, P.; MonBet, Y., AND CANN, C., 1993. Cartographie des zones sensibles à l'eutrophisation, cas des côtes bretonnes. Rapport de synthèse. Convention CEE(DG11)-IFREMER du 31/12/89, Contrat no 6510 90 du C.R. de Bretagne. Commission of the European Communities, DG XI-C.2, Brussels-Conseil Régional de Bretagne, Rennes, France-IFREMER (Institut Français de Recherche pour l'Exploitation de la MER), BP 70, 29263 Plouzané, France, 57p.

Raffaelli, D.G.; Raven, J.A., and Poole, L.J., 1998. Ecological impact of green macroalgal blooms. Oceanography and Marine Biology: an Annual Review, 36, 97-125.

RiegL, B. and Velimirov, B., 1991. How many damaged corals in the Red Sea reef systems? A quantitative survey. Hydrobiologia, 216/217, 249-256.

Rosenberg, R.; Elmgren, R.; Fleischer, S.; Jonsson, P.; PerssON, G., and DAHLin, M., 1990. Marine eutrophication case studies in Sweden. Ambio, 3, 102-108.

Sequi, P.; Benedetti, A.; Bouguerre, M.L.; Chen, Y.; Johnson, D.; Kotzias, D., and Villas-BoAs, L., 1992. Agriculture and pollution of fresh water and of the Mediterranean Sea. In: BERTINI, I.; Scorrano, G.; Cipollini, R., and Monnanni, R. (eds) Depollution planning of the Mediterranean Sea. Recommendations for a sound policy. Societa Chimica Italiana, Firenze, Italy. pp. 29-45.

SFriso, A. and MARCOMINI, A., 1994. Gross primary production and nutrient behaviour in a shallow coastal environment. Bioresource Technnology, 47, 59-66.

Sfriso, A. and MARComini, A., 1996. Macroalgal harvesting and biomass control, benefits and problems: The lagoon of Venice as study case. In: Dion, P. and SchrAmM, W. (eds) COST Action 49. Use of marine primary biomass. Proceedings of workshop, Pleubian, 
France, 20-21 January 1996. CEVA (Centre d'Etude et de Valorisation des Algues), 22610 Pleubian, France, pp. 67-78.

Sfriso, A. and PAvoni, B., 1994. Macroalgae and phytoplankton competition in the central Venice Lagoon. Environmental Technology, 15, 1-14.

Sfriso, A.; Marcomini, A.; Pavoni, B., and Orio, A.A., 1992. Macroalgae, nutrient cycles, and pollutants in the Lagoon of Venice. Estuaries, 15, 517-528.

Sfriso, A.; Marcomini, A.; Pavoni, B., and Orio, A.A., 1993. Species composition, biomass, and net primary production in shallow coastal waters: the Venice Lagoon. Bioresource Technnology, 44, $235-250$.

StIRn, J., 1968. The pollution of the Tunis lake. Rev. Int. Oceanogr. Med., 9, 99-106.

TAgLiaPietra, D.; PAvan, M., and Wagner, C., 1998. Macrobenthic community changes related to eutrophication in Palude della Rosa (Venetian Lagoon, Italy). Estuarine, Coastal and Shelf Science, 47, 217-226.

Thom, R.M. and Albright, R.G., 1990. Dynamics of benthic vegetation standing-stock, irradiance, and water properties in central Puget Sound. Marine Biology, 104, 129-141.

Thomassin, B.A.; Gourbesville, Ph.; Gout, B., and Arnoux, A., 1998. Impact of an industrial and urban sewage off a coral fringing reef at Mauritius (Indian Ocean): modeling of plumes, distribution of traces metals in sediments and effets of the eutrophisation on coral reef communities. Ocean '98 (Nice), pp. 301-305.

Thybo-Christesen, M.; Rasmussen, M. B., and Blackburn, T. H., 1993. Nutrient fluxes and growth of Cladophora sericea in a shallow Danish bay. Marine Ecology Progress Series, 100, 273281.

Topcuoglu, S.; Kirbasoglu, C., and GüngÖr, N., 2002. Heavy metals in organisms and sediments from Turkish Coast of the Black Sea, 1997-1998. Environment International, 27, 521-526.

Turkey, C.M., 1999. The changing Mediterranean Sea--a sensitive ecosystem? Progress Oceanography, 44, 387-400.

Vershinin, A. and Kamnev, A., 2001. Harmful algae in Russian European coastal waters. In: HALLEGRAEFF, S.I.; BlACKBURN, S.I.; BoLCH, C.J., and LewIS, R.J. (eds.), Harmful algal blooms 2000. Proceedings of the ninth international conference on harmful algal blooms (Hobart, Australia, 7-11 February 2000), Paris: UNESCO, pp. 112-115.

Virnstein, R. W. and CARbonara, P. A., 1985. Seasonal abundance and distribution of drift algae and -seagrasses in the mid-Indian River lagoon, Florida. Aquatic Botany, 23, 67-82.

Wilce, R.T.; SchneIder, C.W.; Quinlan, A.V., and VAN DEN Bosch, K., 1982. The life history and morphology of free-living Pilayella littoralis (L.) Kjellm. (Ectocarpaceae, Ectocarpales) in Nahant Bay, Massachusetts. Phycologia, 21, 336-354.

WILKINSON, C.R., 1996. Global change and coral reefs: Impacts on reefs and human cultures. Global Change Biology, 2, 547-558. 